\title{
PRIORITIZATION OF HUMAN CAPITAL DEVELOPMENT STRATEGY OF IMPROVING THE BANK PERFORMANCE
}

\author{
An Nisaa Noor Rachmawati*1, M. Syamsul Maarif ${ }^{*}$, and Anggraini Sukmawati**) \\ *) School of Business, IPB University \\ Jl. Raya Pajajaran, Bogor 16151, Indonesia \\ ${ }^{* *}$ Department of Management, Faculty of Economics and Management, IPB University \\ J1. Agatis, IPB Darmaga Campus, Bogor 16680, Indonesia
}

\begin{abstract}
A human capital strategy is comprehensive planning about how the company achieves its vision and mission through human resources. This study aimed to formulate a prioritization strategy of human capital development for improving company performance used the Analytic Hierarchy Process (AHP). The hierarchy of AHP was arranged by considering five criteria that include an actor, company strategy, human capital management practice, company performance, the role of human capital division, and there were five alternative strategies. A questionnaire of AHP was arranged and presented to seven experts who were chosen from a multinational bank in Indonesia, they provided judgments based on a priority scale for each criterion. The result of the study showed that an actor who was prioritized was the human capital manager. The prioritization of the company strategy was the defender strategy. A human capital management practice that was prioritized was recruitment and selection. The prioritization of company performance was financial and the role of human capital division that was prioritized as a strategic partner. An alternative strategy that was prioritized to be implemented was building effective recruitment and selection systems. In conclusion, the company's performance can be improved through implementing effective recruitment and selection strategies and using validated psychometric instruments.
\end{abstract}

Keywords: Analytic Hierarchy Process (AHP), balanced score card, compensation, performance management, recruitment and selection

\begin{abstract}
Abstrak: Strategi human capital merupakan perencanaan yang komprehensif bagaimana perusahaan dapat mencapai visi dan misinya melalui sumber daya manusia. Penelitian ini bertujuan untuk memformulasikan prioritas strategi pengembangan human capital yang dapat meningkatkan kinerja perusahaan dengan menggunakan Analytic Hierarchy Process (AHP). Hierarki dari AHP disusun dengan mempertimbangkan lima kriteria yang meliputi aktor, strategi perusahaan, praktik manajemen human capital, kinerja perusahaan, peran divisi human capital, serta terdapat lima alternatif strategi. Kuesioner AHP disusun dan disajikan kepada tujuh pakar yang dipilih dari bank multinasional di Indonesia, para pakar memberikan penilaian berdasarkan skala prioritas pada masing-masing kriteria. Hasil penelitian menunjukkan bahwa aktor yang menjadi prioritas dalam formulasi strategi human capital adalah manajer human capital. Prioritas strategi perusahaan yang harus diimplementasikan adalah strategi defender. Praktik manajemen human capital yang diprioritaskan adalah rekrutmen dan seleksi. Prioritas dari kinerja perusahaan adalah keuangan dan peran divisi human capital yang diprioritaskan adalah sebagai mitra strategis. Alternatif strategi yang menjadi prioritas adalah membangun sistem rekrutmen dan seleksi yang efektif. Sehingga dapat disimpulkan bahwa kinerja perusahaan dapat ditingkatkan melalui pengimplementasian strategi rekrutmen dan seleksi yang efektif dan menggunakan instrumen psikometrik tervalidasi.
\end{abstract}

Kata kunci: Analitik Hierarki Proses (AHP), balanced score card, kompensasi, manajemen kinerja, rekrutmen dan seleksi

\footnotetext{
${ }^{1}$ Corresponding author:

Email: annisanoor13@gmail.com
} 


\section{INTRODUCTION}

Currently, the banking industry is being buffeted by a storm of trends and challenges that impact on human capital departments. According to Nzuve and Bundi (2012), there are two fundamental challenges that must be handled by any bank that want to survive in this condition : 1 . The expenses of human capital must be efficient, 2. Workforces must be equipped and trained to handle value adding initiatives.

Human capital is one of the important factors in the company's competitive advantage to win the competition, where these aspects play a role in increasing the potential of human resources to be optimally empowered (Dewi et al. 2017). Therefore, good human capital management is needed so that the company can improve its performance. The results of Mulyaningtyas (2020) study showed the direct effect of human capital on financial performance and value finance at several banks listed on the Indonesia Stock Exchange.

Bank XYZ is one of the Banks in Indonesia that has made employees as capital (human capital) in its business processes. Bank XYZ realizes that the challenges faced today are the need for competent human resources and preparing the employee capabilities to face the era of Volatility, Uncertainty, Complexity \& Ambiguity (VUCA). Human Capital is the most important element in providing the best service for all customers to achieve the company's vision and mission.

Realizing the importance of human capital's role in the company, then needed the appropriate human capital management so able to create human capital as an organization's competitive advantage. This is in line with the resource-based view, the human resource system can contribute to a sustainable competitive advantage through the development of specific competencies suitable for the organization.

The division of human capital has to be a strategic partner to increase company performance. As a strategic partner, human capital needs to encourage the creation of organizational intangible assets such as building a high-performance culture, developing organizational leadership, supporting organizations with the best talent, building organizational knowledge, business processes, and technology and organizational skills. According to Aprinto et al. (2016), the role of the human capital division as a strategic partner is to support long-term business success through human capital management policies and practices.

Human capital management practices are parts of a human capital management that aim to increase/enrich human capital. Some research results showed that human capital management through human capital management practices that aimed to enrich human capital (human capital) could improve operational and financial performance (Keita, 2013; Ajisafe et al. 2015; Alnachef and Alhajjar, 2017).

Realizing that nowadays employees have become capital in its business process and the importance of human capital's roles for the company. Then, in 2018 Bank XYZ increased the cost ratio of employee competency development to $5.05 \%$. But, the increase of this investment couldn't push the customer's performance perspective.

In 2018, there was an increasing number of customer complaints from 19,668 became 21,677 in 2018 . This was followed by the decrease in Relationship Strength Index (RSI) in 2017 by 7.60 to 7.51 in 2018. This indicated that the magnitude of investment did not always generate a positive outcome for company performance.

Therefore, the company needs to develop a human capital strategy that contains policies or practices that able to develop human capital competence to achieve the expected performance, so able to add value to the company. According to Wilson and Mampilly (2014), human capital practices were a set of practices that focus on organizational needs to provide certain competencies.

Through human capital development strategy can create employee competence and capability as capital to improve the company's performance. The application of human capital strategies had a positive impact on employee performance and create productivity (Caliskan, 2010; Kristyawan and Sutanto, 2014). This study aimed to formulate an alternative strategy of human capital development that improve the company's performance with the analytic hierarchy process method. 


\section{METHODS}

This study used a cross-sectional study design with a quantitative approach and supported by qualitative data. Quantitative approaches aimed to obtain paired comparison data. Qualitative data was collected through an interview method to the respondent to obtain information about the variables in this study. This study was conducted from January until March 2020. The location of this study at Bank XYZ located in Jakarta. The location was chosen purposively based on criteria the company which has made humans as capital in its business processes.

This study was conducted by using a structure approach model of Analytical Hierarchy Process (AHP) with software Expert Choice 2000 as instrument to know structure and strategy alternative priority. This study used two data sources, primary and secondary data. Primary data were obtained by in-depth interviews with the experts and secondary data in from of literature studies and annual reports supporting the company's performance.

The experts selected purposively with criteria someone who has capability, experience, and influence in the policies. They provided judgments based on a priority scale for each criterion. The experts were five human capital managers, one operational risk manager, and one litigation manager (Table 1).
Human capital development strategy for increasing company performance is generated by analytic hierarchy process. According to Saaty (2008), there were four stages in AHP analysis (Figure 1). First, define the problem and determine the kind of knowledge sought. Second, Structure the decision hierarchy from the top with the goal of the decision, then the objectives from a broad perspective, through the intermediate levels (criteria on which subsequent elements depend) to the lowest level (which usually is a set of the alternatives). Third, construct a set of pairwise comparison matrices. Each element in an upper level is used to compare the elements in the level immediately below with respect to it. Fourth, Use the priorities obtained from the comparisons to weigh the priorities in the level immediately below. Do this for every element. Then for each element in the level below add its weighed values and obtain its overall or global priority. Figure 1 show the stages of AHP.

Continue this process of weighing and adding until the final priorities of the alternatives in the bottom most level are obtained. To make comparisons, we need a scale of numbers that indicates how many times more important or dominant one element is over another element with respect to the criterion or property with respect to which they are compared (Table 2).

Table 1. The experts based on position, number, and the origin of division

\begin{tabular}{lll}
\hline Position & Number & The origin of division \\
\hline Manager & 5 & $\begin{array}{l}\text { Business human capital,human capital operations, employee relations \& health safety, re- } \\
\text { wards, organization development \& strategy, talent management \& organization learning }\end{array}$ \\
Manager & 1 & $\begin{array}{l}\text { Operational risk } \\
\text { Manager }\end{array}$ \\
\hline
\end{tabular}

Table 2. Exhibits the scale

\begin{tabular}{ll}
\hline Intensity of impotance & Definition \\
\hline 1 & Equal importance \\
3 & Moderate importance \\
5 & Strong importance \\
7 & Very strong or demonstrated importance \\
9 & Extreme importance \\
$2,4,6,8$ & If the activities are very close \\
Reciprocals of above & If activity i has one of the above non zero numbers assigned to it when compared with activity $\mathrm{j}$, \\
& then $\mathrm{j}$ has the reciprocal value when compared with i \\
\hline
\end{tabular}




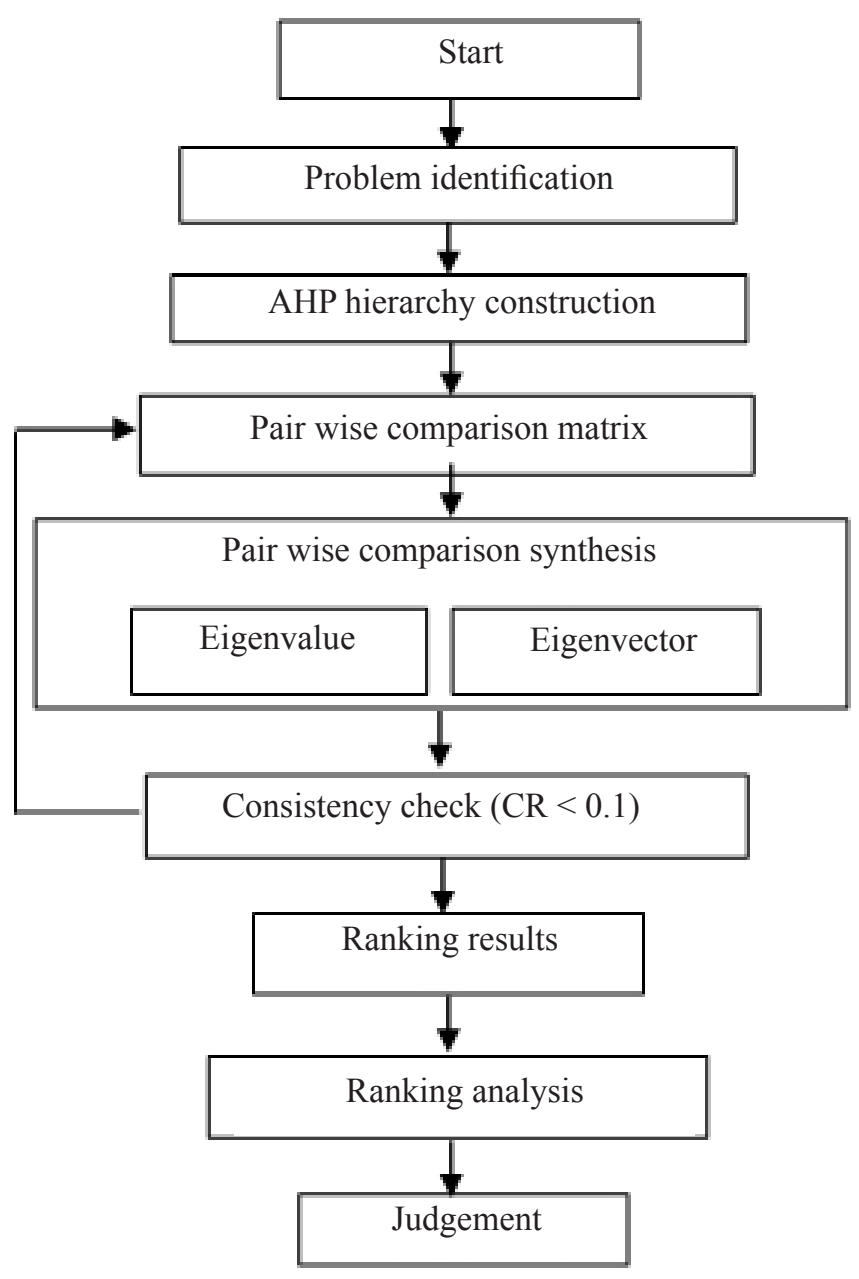

Figure 1 The stages of AHP (Sael et al. 2019)

The initial process in this study is to arrange a hierarchy from literature studies and discussions with experts in their fields to find out information related to research needs. Based on the results ofinterviews and discussions, a hierarchy will be developed that generates a human capital strategy to improve the performance of Bank $\mathrm{XYZ}$. Here is a picture of the hierarchical structure of the formation of human capital strategies to improve performance in this study (Figure 2).

The structure of hierarchy was arranged based on literature studies, interviewed with experts, and considered the result of other analyzes that was part of this research. The factors roles of the division of human capital and the practice of human capital management had a positive and significant influence on the factor of company performance, so these were included in the hierarchical structure of AHP, while for the actors obtained through interviews with experts. Meanwhile, factors such as corporate strategy and alternative strategies were obtained through literature studies.
According to Kaplan and Norton (2006), the company could obtain higher profits if they were able to carry out the human capital alignment, which was aligning company strategy with goals of employee, training, and incentives that were provided. Alternative strategies were obtained through a critical review of human capital strategies that can improve company performance (Lam et al. 1999; Bjornberg, 2002; Duraisingam, 2005; Duraisingam \& Skinner, 2005; Ameritrade, 2012).

\section{RESULTS}

\section{Vertical Processing}

Vertically data processing aimed to obtain the priority from each hierarchy element toward the goals human capital strategy to improve company performance. The hierarchy structure is described in Figure 3 which consists of seven levels: (1) The level of goals to formulate a human capital strategy to improve company performance; (2) The level of an actor consists of a human capital manager, operational risk manager, and litigation manager; (3) The level of company strategy consists of defenders, prospectors, analyzer, and reactors strategy; (4) The level of human capital practices consists of recruitment and selection, compensation, training and development, performance appraisal, and career development; (5) The level of company performance consists of financial, customer, business process, and learning and growth; (6) The level of human capital division's roles consists of strategic partner, administrative expert, employee champion, and change agent; (7) The level of the alternative strategy comprise some of the human capital strategies to improve company performance.

\section{Element Actor on Human Capital Strategy to Improve Company Performance}

Table 3 shows the weight and priority of each actor in the formulation human capital strategy to improve company performance. Actors that were including in this study were human capital manager, operational and risk manager, and litigation manager. An actor who had a high priority in the formulation of a human capital strategy to improve company performance in Bank XYZ was a human capital manager with a weight of 0.684 . 


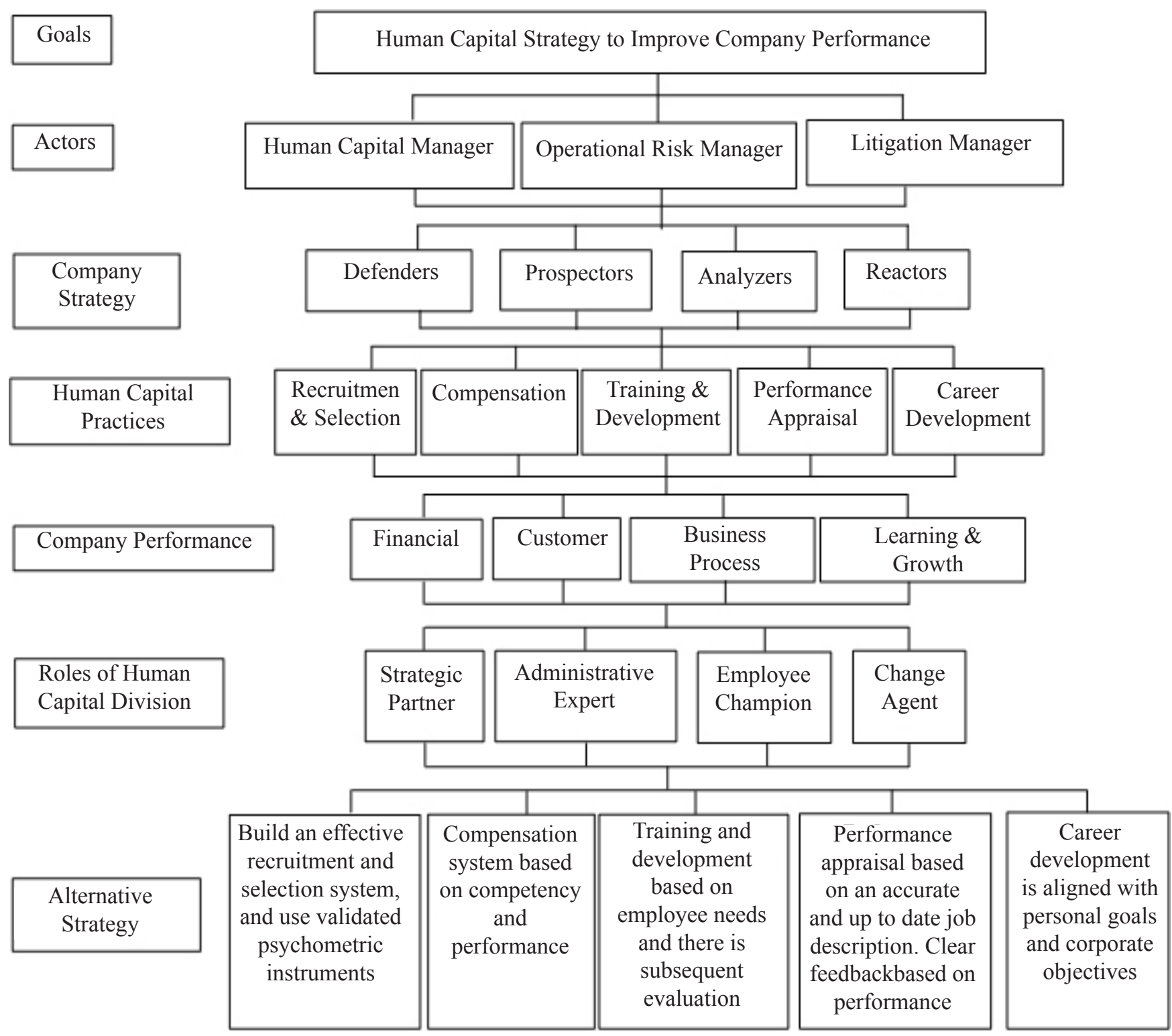

Figure 2. The hierarchy of human capital development strategy to improve company performance

Table 3. Actors based on weights and priorities

\begin{tabular}{lcc}
\hline Actor & Weight & Priority \\
\hline Human capital manager & 0.684 & 1 \\
Operational risk manager & 0.191 & 2 \\
Litigation manager & 0.125 & 3 \\
\hline
\end{tabular}

The human capital manager was an important actor in the formulation of human capital strategy. According to Bamberger et al. (2014), human capital strategy referring to some of the human capital practices that formulated by a human capital manager and senior management which aimed achieve certain goals related to human capital. The human capital manager had an important role to make a human capital strategy that improved company performance.Meanwhile, other actors involved in the formulation of the human capital strategy were operational risk manager and litigation manager with each weights of 0.191 and 0.125 . A human capital strategy can improve company performance if it was aligned with business strategy. So, it can be concluded that in the formulation of human capital strategy, a human capital manager had dominant roles however involvement another division manager was needed so the strategy which was generated can push performance from each division and in the end can improve company performance. 


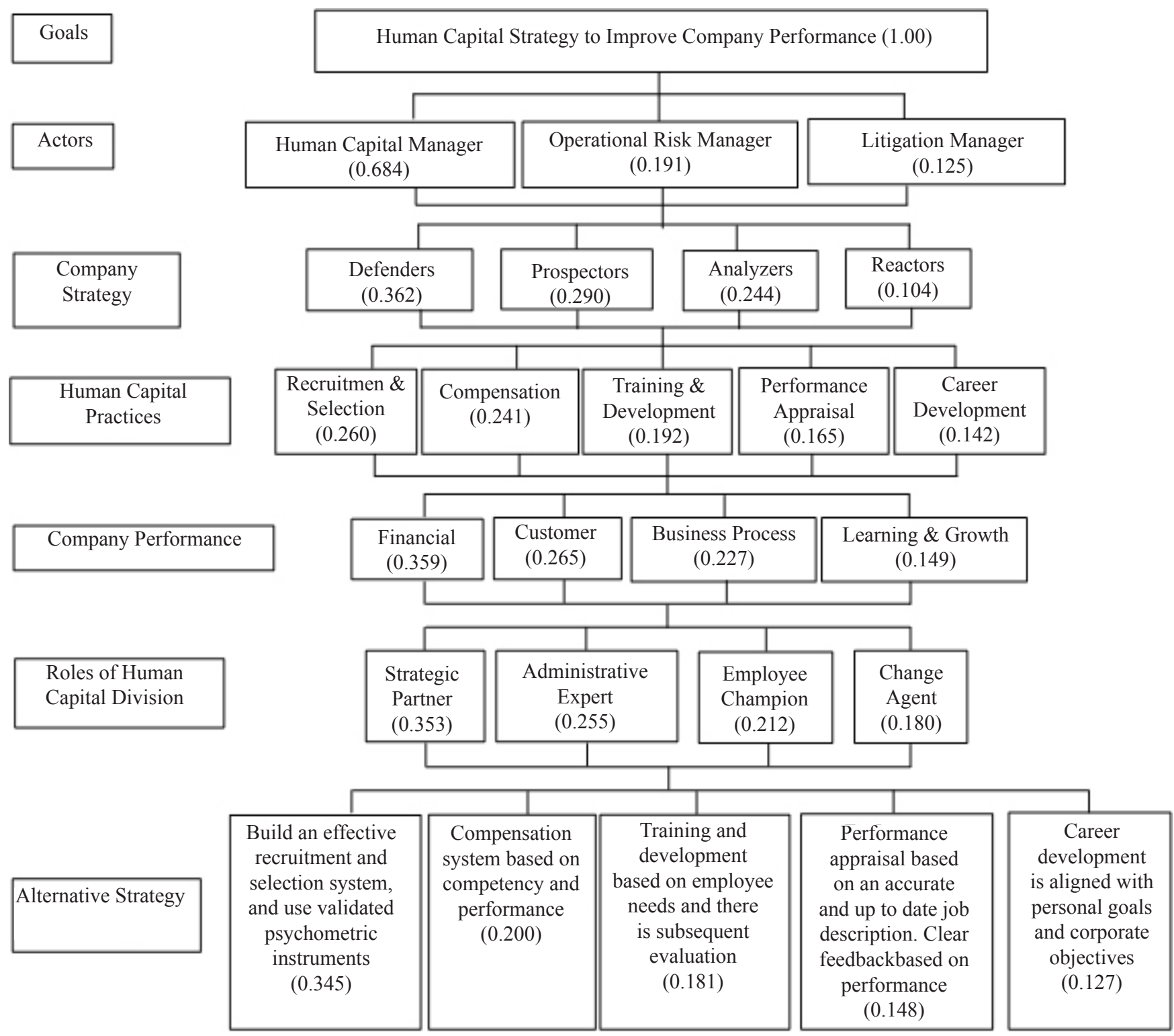

Figure 3. The weight of each criterion in the formulation of human capital development strategy to improve company performance

\section{Company Strategies Element on Human Capital Strategy to Improve Company Performance}

Table 4 shows the type of company strategy that had a primary priority to be implemented to improve the company performance was the defender's strategy with a weight of 0.362 . Prospectors occupied the second position with a weight of 0.290 as the type of company strategy that was important to be implemented. Meanwhile, analyzers and reactor's strategy occupied third and fourth positions with the weight of each of 0.244 and 0.104 .

Based on a global and domestic economic condition that was slowing down due to the continuing trade war between AS and China. Nowadays, the defender's strategy was the most important strategy to be implemented in Bank XYZ. Bank XYZ needed to carry out risk management, for instance, profit management to survive in this condition. Profit management needed to carry out to maintain reputation of Bank XYZ as a stable company in front of customers and investors.

In line with Widyasari et al. (2017) that prove there was a relationship between the business strategy selected with the high level of profit management that was caused by the high expectation investor toward the company. The reputation as a stable company will make the investor sure to invest or save their money, so they can improve the performance of Bank XYZ. Therefore, Bank XYZ needs to implement a defender strategy as an effort to improve performance. 


\section{Human Capital Practices Element on Human Capital Strategy to Improve Company Performance}

In this study, human capital practices were including recruitment and selection, compensation, training and development, performance appraisal, and career development. Table 5 shows the weight and priority of human capital practices. The human capital practice that had primary priority to be implemented to improve company performance was recruitment and selection with a weight of 0.260 . Based on Table 5, a human capital practice that occupied the second position with a weight of 0.241 was compensation practice. The third priority was occupied by training and development with a weight of 0.192 . Meanwhile, fourth and fifth priorities were occupied by performance appraisal and career development with the weights of each of 0.165 and 0.142 .

Recruitment and selection practice had a big impact on company performance. Because of this stage company gathered and selected the best candidate to be its human resource. Recruitment and selection had an important role in forming organization effectiveness and performance. If the company can recruit and select employees effectively, then the company can avoid unwanted cost as high turnover, bad performance, and customer dissatisfaction (Saviour et al. 2016).

\section{Company Performance Element on Human Capital Strategy to Improve Company Performance}

In this study, perspective of company performance were including financial, customer, business process, learning and growth. Table 6 shows the weight and priority of company performance based on each perspective. The perspective of company performance that had primary priority for improving company performance was a financial perspective with a weight of 0.359 .

Next, the customer perspective was the second performance priority to be improved with a weight of 0.265 . Meanwhile, the third position was occupied by the business process perspective with weight of 0.277 . Then the fourth positions was occupied by learning and growth perspective with the weights of each of and 0.149 .

Financial performance was the most important performance perspective to improve performance's a company in the banking field. Due to a financial performance was a key indicator of the success of a bank for the customer. Furthermore, through financial performance customers can analyze how the bank manages their capital.

Table 4. The type of company strategies based on weights and priorities

\begin{tabular}{lcc}
\hline The type of company strategy & Weight & Priority \\
\hline Defenders & 0.362 & 1 \\
Prospectors & 0.290 & 2 \\
Analyzers & 0.244 & 3 \\
Reactors & 0.104 & 4 \\
\hline
\end{tabular}

Table 5. The human capital practices based on weights and priorities

\begin{tabular}{llc}
\hline Human capital practices & Weight & Priority \\
\hline Recruitment and selection & 0.260 & 1 \\
Compensation & 0.241 & 2 \\
Training and development & 0.192 & 3 \\
Performance appraisal & 0.165 & 4 \\
Career development & 0.142 & 5 \\
\hline
\end{tabular}

Table 6 . The perspective of company performance based on weights and priorities

\begin{tabular}{lcc}
\hline The perspective of company performance & Weight & Priority \\
\hline Financial & 0.359 & 1 \\
Customer & 0.265 & 2 \\
Business process & 0.227 & 3 \\
Learning and growth & 0.149 & 4 \\
\hline
\end{tabular}


According to Pratiwi and Handayani (2018) said that financial performance assessment was an important thing for a bank and can be used to assess the success of the bank. Next, customer performance, business process, and learning and growth were performance perspective that can push financial performance. The success of the bank in gaining a large profit cannot be separated from the other performance that was generated by human resources in the bank.

\section{Human Capital Division's Role Element on Human Capital Strategy to Improve Company Performance}

The roles of human capital division that were analyzed in this study were strategic partner, administrative expert, employee champion, and change agent. Table 7 shows the role of strategic partner was the most important role that had to be implemented by human capital division with a weight of 0.353 . Because currently, employees were the human capital of the company. Hence, nowadays human capital division had a strategic function and was demanded to be able to resolve strategic issues within the company.

As a strategic partner, the human capital division needs to align human capital strategy with business strategy. According to Mitchell et al. (2013), as a strategic partner human capital division participated in the development and implementation organization strategy. The primary function of human capital division as a strategic partner was to align human capital strategy and business strategy (Ulrich, 1997).
The alignment between human capital strategy and business strategy will generate the better of company performance. Based on the opinion of Wang and Shyu (2008), the alignment between human resource strategy and business strategy was a key success in the company. To achieve its success, the company needed to ensure that business strategy was connected with human resource management activities (Jhajharia and Kaur, 2015). Because, when a business and human resource strategy were aligned then the effectiveness of human resource practice and performance organization will be better than were unsynchronized.

\section{Alternative Strategy Element on Human Capital Strategy to Improve Company Performance}

Table 8 shows the weight and priority of each roles of human capital division in the formulation human capital strategy to improve company performance according to experts. The alternative strategy that had primary priority to be implemented for improving company performance was building an effective recruitment and selection system, and use validated psychometric instruments (0.345). The second position was occupied by an alternative strategy compensation system based on competency and performance $(0.200)$.

Based on Table 8, alternative strategy training and development based on employee needs occupied the third position with a weight of 0.181 . Meanwhile, the fourth position was occipied by alternative strategy performance appraisal (0.148). And then the fifth position was occupied by career development $(0.127)$.

Table 7. The roles of human capital division based on weights and priorities

\begin{tabular}{lcc}
\hline The role of human capital division & Weight & Priority \\
\hline Strategic partner & 0.353 & 1 \\
Administrative expert & 0.255 & 2 \\
Employee champion & 0.212 & 3 \\
Change agent & 0.180 & 4 \\
\hline
\end{tabular}

Table 8. The Alternative strategies based on weights and priorities

\begin{tabular}{lcc}
\hline Alternative strategy & Weight & Priority \\
\hline Build an effective recruitment and selection system, and use validated psychometric instruments & 0.345 & 1 \\
Compensation system based on competency and performance & 0.200 & 2 \\
Training and development based on employee needs and there is subsequent evaluation & 0.181 & 3 \\
Performance appraisal based on an accurate and up to date job description. Clear feedbackbased & 0.148 & 4 \\
on performance & & \\
Career development is aligned with personal goals and corporate objectives & 0.127 & 5 \\
\hline
\end{tabular}


Bank XYZ has made employees as capital (human capital) in its business processes, so that was important for the company to gather and select the best candidate who will be the resource in the company. According to Mutiara et al. (2019), the implementation of a good recruitment and selection strategy could help company to get employees with their best talents. Also, according to Oaya et al. (2017), the strengths and weaknesses of an organization came from the quality of its employees, through a good recruitment and selection strategy allowed the company to obtain the right and qualified employees for improving company.

Nowadays, one of the challenges that was faced by Bank XYZ was the competition with strat up company for gathering the best candidate. Meanwhile, the lowest of young employee commitment on organization caused the high rate of turn over and impacted on company performance. Based on the results of interviews with experts, it was known that the majority of employees who resigned came from the sales division. Most of the reasons they left were due to choosing another bank or start-up company.

According to Duraisingam (2005), the recruitment and selection process could influence a candidate's decision to receive a job offer, and their commitment to stay with the organization. Therefore, it was important for companies to build effective recruitment and selection systems and to use validated psychometric instruments that can detect early on how the candidate commits to the company. It was supported by Singh and Kassa (2016) opinion that stated good recruitment and selection systems were without prejudice in the beginning and developed by managerial experts, the used of standardized tests to properly examine the attitudes, skills, and knowledge that the candidates had positively correlated to the perception of organizational performance.

According to the experts, all the practice in human capital practices was holistic so couldn't be separated one practice with another practice. An expert opined that the right selection of people, the compensation system as liked was expected, feeling of appreciated, getting good treatment, training, identification of self-development could improve the employee's performance. Because when the employee felt comfortable and safe while they were working, they would increase their contribution.
Moreover, if the improvement of practice was not followed by other practices it could apparently employee dissatisfaction. One of the experts had an opinion about the increase in compensation without the opportunity of training would make employees feel dissatisfied and choose to leave the company. In conclusion, the best practice of human capital was the integrated human capital practice with each other so as creating a comfortable and safe feeling for employees so in the end could drive the performance of Bank XYZ.

\section{Managerial Implications}

As an effort for improving company performance, the company needed to implement an alternative strategy that to be priority was building an effective recruitment and selection system, and use validated psychometric instruments. Bank XYZ continues to improve its productivity by focusing on the fulfillment of the best quality of human capital in all positions, especially sales force and customer service positions. Through the recruit right program, it sought to get high-quality, high-integrity candidates who could adapt to changes and had superior competence accordingly company needs. One of the efforts that could carry out to get candidates with these criteria was the company needed to build an effective recruitment and selection system and used a validated psychometric instrument that can detect early on how the candidate's commitment to the company.

\section{CONCLUSIONS AND RECOMMENDATIONS}

\section{Conclusions}

In this study, an alternative strategy of human capital development strategy to improve the performance that was selected by the experts was effective recruitment and selection systems and using validated psychometric instruments. The reason why this alternative strategy was chosen because through the practice of recruitment and selection the company could obtain the employee who had the high-quality, high integrity, high commitment, could adapt to changes and had superior competence accordingly company needs so that in the end it could contribute to better company performance. Moreover, to obtain optimal results, companies need to integrate every human capital practice. 


\section{Recommendations}

Based on the result of this study Bank XYZ needs to improve financial performance. Financial performance is an indicator of the success of a bank for customers so it is important to be improved. Furthermore, based on the result of the interview Bank XYZ needs to provide a medical check-up for all the candidates. It is important to carry out because the health of a candidate is a primary capital to create performance productivity.

\section{REFERENCES}

Ajisafe E O, Orifa R A, Balogun J A. 2015. Influence of human capital management on organizational performance. Journal of Resources Development and Management 14(1): 8-14.

Alnachef T H, Alhajjar A A. 2017. Effect of human capital on organizational performance: a literature review. International Journal of Science and Research 6(8): 1154-1158.

Ameritrade Institusional. 2012. Developing a Compensation Strategy. Toronto: TD Ameritrade IP Company, Inc.

Aprinto B, Kuswanda H, Chosasih C, Latif A, editor. 2016. Revolusi Human Capital. Jakarta: PPM.

Bamberger P A, Biron M, Meshoulam. 2014. Human ResourceStrategy: Formulation, Implementation, and Impact. New York: Routledge.

Bjornberg L. 2002. Training and development: best practices. Public Personnel Management 31(4): 507-516.

Caliskan Esra N. 2010. The impact of strategic human resource management on organizational performance. Journal of Naval Science and Engineering 6 (2) : 100-116.

Dewi K R, Negoro N P, Rahmawati Y. 2017. Peran human capital terhadap efisiensi perusahaan perbankan di Indonesia. Jurnal Sains dan Seni ITS 6(1): 24-27.

Duraisingam V, Skinner N. 2005. Performance Appraisal: Workforce Development TIPS (Theory Into Practice Strategies). In N. Skinner, A.M. Roche, J. O'Connor, Y. Pollard, C. Todd, editor. Australia: Flinders University.

Jhajharia P, Kaur R. 2015. Achieving strategic-fit between business and human resource strategies. International Journal of Humanities and Social Science Invention 4 (1): 53-61.

Kaplan R S, Norton D P. 2006. ALIGMENT: Using the Balanced Scorecard to Create Corporate Synergies. United State of Americ: Harvard Business School Press.

Keita R. 2013. The impact of human capital management on operational performance at the gambia national water and electricity company (NAWEC)[tesis]. Ghana: Kwame Nkrumah University of Science and Technology.

Kristyawan R, Sutanto E M. 2014. Peranan strategi human capital di PT. Andhika Solo megah. AGORA 2 (2): 1-4.

Lam N, Dyke L, Duxbury. 1999. Career development in best-practice organizations:critical success factors. Optimum, The Journal of Public Sector Management 29(4): 22-30.

Mitchell R, Obeidat S, Bray M. 2013. The effect of strategic human resource management on organizational performance: the mediating role of high-performance human resource practices. Human Resource Management 52 (6): 899-921

Mulyaningtyas. 2020. Pengaruh human capital terhadap kinerja keuangan dan nilai perusahaan. Jurnal GeoEkonomi 11(1): 47-56.

Mutiara N, Hubeis A V, Sukmawati A. 2019. Talent management in improving the employees performance of PT PLN (persero) TJBB APP Cawang. Indonesian Journal of Business and Entrepreneurship 5(1): 96-106.

Nzuve S, Bundi E. 2012. Human capital Management Practices and Firms Performance: A Survey of Commercial Banks in Kenya. SSRN[Internet]. [diunduh pada 2019 Sep 09]. Tersedia pada: https://dx.doi.org/10.2139/ssrn.2144691.

Oaya Z, Ogbu O, Remilekun O. 2017. Impact of recruitment and selection strategy on employees' performance: a study of three selected manufacturing companies in Nigeria. International Journal of Innovation and Economics Development 3(3): 32-42.

Pratiwi S dan Handayani S R. 2018. Analysis of financial performance indonesia sharia banks (empirical study on muamalat bank, bri sharia, bni sharia, and bank sharia mandiri). Jurnal Administrasi Bisnis (JAB) 63 (1): 140-147.

Saaty T L. 2008. Decision making with the analytic hierarchy process. International Journal of Services Sciences 1(1): 83- 98.

Sael N, Hamim T, Benabbou F. 2019. Implementation of the analytic hierarchy process for student profile analysis. International Journal of Emerging Technologies in Learning 14(15): 78-93. 
Saviour A W, Kofi A, Yao B D, Kafui L A. 2016. The impact of effective recruitment and selection practice on organisational performance (a case study at university of Ghana). Global Journal of Management and Business Research: A Administration and Management 16(11): 25-34.

Singh N R, Kassa B. 2016. The impact of human resource management practice on organizational performance: a study on Debre Brehan University. International Journal of Recent Advances in Organizational Behaviour and Decision Sciences 1(1): 643-662.

Ulrich D. 1997. Human Resource Champion. Boston: Harvard Business School Press.
Wang D S, Shyu C L. 2008. Will the strategic fit between business and HRM strategy influence HRM effectiveness and organizational performance? International Journal of Manpower 29 (2): 92110.

Widyasari P A, Harindahyani S, Rudiawarni F A. 2017. Strategi bisnis dalam praktik manajemen laba pada perusahaan manufaktur di indonesia. Jurnal Keuangan dan Perbankan 21 (3): 397-411.

Wilson N, Mampilly S R. 2014. The role of human capital management practices in inculcating learning orientation and its relationship with performance: a systematic literature review. Journal of Business and Management 16 (7): 15-22. 